\title{
Funding Innovation in Poland through Crowdfunding
}

\section{Katarzyna Kozioł-Nadolna ${ }^{1}$}

\begin{abstract}
Funding innovative projects is one of the most serious problems faced by business owners in Poland. Therefore, due to the difficulties of obtaining external sources of financing, crowdfunding may constitute a new source of fundraising for innovative ventures. Therefore, crowdfunding - as a way of raising capital for projects - is the subject of the discussion in this article. The research aim of the article is to identify and evaluate crowdfunding platforms as well as the innovative projects carried out by these platforms in Poland in 2014-2016. The first part characterizes crowdfunding as a source of funding innovation and presents the nature of crowdfunding, its characteristics and models. The empirical part is based on inductive-deductive inference, desk research, i.e. the analysis of crowdfunding market in Poland in two research periods and a case study analysis. The article shows the results of the research on the Polish crowdfunding market in 2014-2016. The author also presents a case study of funding innovation on the Kickstarter.com platform by a Polish company Sher.ly.
\end{abstract}

Keywords: innovation, crowdfunding, funding innovation, Poland.

\section{INTRODUCTION}

The European Union defines innovation as one of the most important factors which is going to determine the competitiveness of the economy in the coming years. By the term 'innovation', one understands an ability and motivation of entrepreneurs to undertake a permanent search and take advantage of the results of this research, new ideas, concepts and inventions. Moreover, innovation involves improvement and development of production and operating technologies which also refer to services, the application of new solutions in organization and management, progress in the development of infrastructure, and, first and foremost, information, with its gathering, processing accessibility (Janasz \& Kozioł, 2007).

1 Katarzyna Kozioł-Nadolna, Professor US, University of Szczecin, Faculty of Economics and Management, ul. Mickiewicza 69, 71-101 Szczecin, Poland, e-mail: Katarzyna.Kozioł-Nadolna@usz.edu.pl. 
According to the latest theories and practice, innovations are the result of numerous, complex interactions among units, organizations and the environment in which they operate. The development of innovation theories and processes shows further evolution of these phenomena and together with all processes in today's economy it will result in the emergence of more complex and realistic models of innovation process. Extensive changes in the practice of implementing innovations, in their kinds and forms or character, notably observed since the beginning of the 21th century, prompted the OECD to announce the Innovation Strategy (Organization for Economic Cooperation and Development [OECD], 2009), a document describing new features of this phenomenon. The following are the characteristics of a contemporary innovation:

- it is created by the participation of a greater number of participants than before,

- it is created by overlapping and fusion of a greater number of areas of knowledge,

- it is created within more diverse mechanisms (open and closed innovations, demand-driven innovations, innovations created within consortia etc.),

- it takes place within an increasingly diversified environment (research consortia, technology transfer centers and technology platforms, new technology companies, venture capital companies, knowledgeintensive business services, clusters, non-profit organizations),

- in an innovation activity a stronger emphasis is put on decentralization of project management, plasticity of an organization, staff autonomy, stimulating creativity, building mutual trust, and on communication and leadership (OECD, 2009),

- customers and users are becoming co-authors of innovations,

- anonymous groups are authors of innovations (Wikipedia, Linux),

- the significance of non-technological innovations is growing steadily,

- one can observe the growing importance of eco-innovations, social innovations and 'modest' innovations,

- an emphasis is put on hybrid value chains - the cooperation aiming to integrate innovations and entrepreneurship of a business sector with that of a social sector,

- growing globalization of research and development.

In 2012 the OECD in its report Science, Technology and Industry Outlook (Organization for Economic Co-operation and Development [OECD], 2012) said that innovations, once seen as the domain of developed countries, are now appearing in many emerging countries and their share is constantly increasing. Even the implementation of new technologies from abroad requires some adaptation and adjustment, which can already be considered innovation. The report emphasizes that the concept of innovation goes far 
beyond the advanced technology as it also covers technology at a lower level, the service sector and social innovations. A world-class scientific database is not a necessary prerequisite for innovation. Innovation can help in reducing poverty (which is a priority for many countries, in particular developing ones). Modest innovations exert a more direct impact as they make new products more readily available to households with low and middle-income, and poor people can modernize their businesses, often those "informal" ones and with a low level of productivity.

Due to the newly appearing types and forms of contemporary innovation and a shift of paradigm from closed to open, in addition to traditional sources of funding innovation projects, there are new ones appearing. Innovation can be financed from different sources, e.g. own resources of organizations, external resources, or funding obtained from the web community (crowdfunding). Crowdfunding has been growing rapidly in the past few years as advancements in technology and the growth of social media has made it far easier for entrepreneurs to reach large numbers of people at far less cost (Pierrakis \& Collins, 2013).

Funding innovative projects is one of the most serious problems dealt with by business owners in Poland. The lack of capital for the realization of innovative projects can translate into a deterioration of a company's competitive position. Thus, capital is the basis for the development of innovative enterprises.

Access to financial resources is also one of the most urgent problems for European SMEs (European Commission [EC], 2013). For many projects, financing needs are not met by existing sources of financing, which is defined as the funding gap.

Crowdfunding may prove to be a support for entrepreneurship both in terms of improving access to funding and in the context of additional market research and marketing tools that can help entrepreneurs obtain comprehensive knowledge of their customers and promotion in the media (European Commission [EC], 2014, p. 5).

The abovementioned research problem indicates that crowdfunding as a way, or an alternative source, of funding a variety of innovations is the subject of the discussion. The research aim of the article is to identify and evaluate crowdfunding platforms as well as the innovative projects carried out by these platforms in Poland in 2014-2016. The thematic scope of the article and its aim determine the applied research approach. The theoretical part was grounded on deductive inference and comparative analysis on the basis of subject literature analysis, whilst the empirical part was based on inductivedeductive reasoning, a desk research, i.e. the analysis of crowdfunding market in Poland in two research periods and a case study analysis. 


\section{LITERATURE REVIEW}

\section{Innovation processes, open innovation and crowdfunding}

In defining an innovation process we can distinguish two definitions. According to Schumpeter (1960) the innovation process is a certain sequence of events: starting from an idea (invention), through implementation (innovation) and dissemination (imitation). Janasz and Kozioł-Nadolna (2011) define an innovation process as generating an innovation idea (regardless of what the idea is about or what area of innovation activity it is created on), then creating, designing and the first implementation. The main event in this kind of process is the implementation of a new product or solution. The innovation process, as the definition says, consists of phases, stages connected to each other by different interactions.

We can look at innovation processes from different perspectives: economy, enterprise or a separate innovation. No matter which analysis we use, an innovation process generally consists of two phases: the creation of an innovation and its dissemination.

Innovation models have evolved from simple linear models. Good examples are: the technology-push model (up to the second half of the 1960s) and the market-pull model (in the 1970s). More recent innovation models try to build more complexity and interaction into the framework and explicitly stress the need for openness towards external partners in innovation and R\&D. The "third-generation" innovation model combines the technology-push and need-pull models by stressing linkages and feedback loops between R\&D and marketing. The subsequent integrated model of the 1980s ("fourth-generation") emphasised innovation as a broadly parallel process with cross-functional integration and parallel development within the company and with external collaborators. Rothwell (1992) claimed at the beginning of the 1990s that there were five generations of innovation models. His last 'fifth-generation' model combines integration networking with information technology, based on networking of marketing, R\&D, production and customers.

Can we already start talking about the "sixth-generation" innovation model? The answer seems to be positive (Nobelius, 2004, pp. 369-375; Ahmed, 2000, pp. 112-114; Baruk, 2006, p. 122). The end of the 1990s and the first decade of the 21st century brought new solutions, structures and, finally, a new approach towards development. Thus, the 'sixth-generation' model is an answer to the changes in the global environment and its influence on enterprises. Moreover, the enterprises themselves have changed: their structure, ties (so networking enterprise emerged), an emphasis on 
cooperation. In this model attention is paid to knowledge as a separate category and the processes managing the knowledge as well as learning processes. Innovation processes should be planned in a way to enable the following: creating new knowledge, managing existing knowledge, storing up knowledge, transfer of knowledge, or using it again. Different kinds of boundaries are crossed: between enterprises, between sectors participating in innovation processes, in taking advantage of the experience of many organizations and their employees. Finally, new problems have emerged, e.g. the protection of intellectual property and regulations in an innovation chain.

The 21st century strengthened the substantial changes in the market, which made enterprises change their innovation models. The innovation process is becoming more expensive and risky due to global competition, a short product cycle, and technological progress. As a consequence, enterprises start to share the risk by doing research with other enterprises and organizations, applying the open innovation model and entering enterprise networks.

In the open strategy of innovations the following rule is the most basic: the maximization of values coming from different ideas (both the company's ideas as well as the external ones). This approach means that the formal framework of organization is just symbolic and does not stop the flow of knowledge between the organization and its environment. Companies that adopt the open innovation strategy both enthusiastically develop ideas which were created by others, as well as making their own ideas available to other organizations which find them more interesting. Sometimes a company's own ideas are transferred to other enterprises deliberately (e.g. start-ups) in order for them to be developed without the influence of the company's own internal powers (Chesbrough, 2003).

The novelty of Chesbrough's concept was based on the fact that the process of open innovation became an integral part of the innovation strategy of an enterprise and its business model. In the first decades of the 20th century industrial enterprises in the USA cooperated and ordered solutions from external R\&D laboratories. We can say that they used the open innovation model (Teece, 1988). However, the situation changed drastically after the Second World War. In the 1950s and 1960s the first generation model of the innovation process (described in the previous chapter) with its closed approach was in the lead. The new open innovation model contrasts with this approach.

In the closed approach, organizations do not share their knowledge and, moreover, their ideas stay inside an enterprise, being assessed at various times. A lot of ideas are rejected and never used. On top of that, they are 
eliminated, not by the market or consumers, but by employees of the enterprise who find the ideas irrelevant or useless at the time.

In this model, enterprises finance innovation processes only from their own resources, which are often very meagre, as the R\&D activity is risky. And therefore, enterprises will often tend to purchase ready-made material technology. On the market there is free capital, which may be intended for the development of innovation projects (e.g. through strategic alliances, cooperation agreements, venture capital, business angels' activity). However, this requires a radical change in thinking about innovation. One of the ways out of this situation is to be open to the environment, e.g. customers, suppliers, and institutions such as universities, by making them deeply involved in their innovation processes.

Therefore, it can be concluded that one of the elements of openness of an innovation process is "opening" oneself to resources from outside the organization - i.e. alternative resources to traditional ways of financing. Such a solution is crowdfunding. In the open innovation model crowdfunding seems to be a good source of raising capital. It is the optimal choice for young entrepreneurs with attractive business ideas. Apart from the financial dimension, the advantages of raising capital within the open innovation model are (Malinowski, 2016):

- brand promotion and publicity,

- co-creation of products or services by Internet users,

- validation of a project in the eyes of professional investors,

- a chance to bring communities and brand ambassadors together,

- building a network of contacts.

Among the disadvantages of this method of raising capital are:

- the necessity to split shares and a potential loss of full control over the company,

- lack of marketing support, which is frequently obtained as an investment package from professional institutions,

- lack of know-how transfer.

\section{The nature and characteristics of crowdfunding}

The phenomenon of crowdfunding is part of a broader concept called crowdsourcing, i.e. treating a crowd or, in other words, a community as a source of various resources. In 2006, the term crowdsourcing was first used by Jeff Howe in Wired Magazine - Howe defined crowdsourcing and also provided examples of its variations and identified the following (2006):

- Crowd Creation - a form of community involvement to look for new solutions, it is a genuine talent demonstrated by people in the crowd - together or separately. Its effect is the creation of Linux, Wikipedia, 
iStockphoto, Innocentive, TopCoder and many other projects or companies.

- Crowd Voting, the most popular form of crowdsourcing involving many participants, e.g. in a vote on a new name of a drink, a brand of a car, the choice of participants in a music program.

- Crowd Wisdom, 'wisdom of the crowd', is an attempt to collect and compile many individual judgments and opinions in order to solve a problem, prepare a prognosis and outline a corporate strategy.

- Crowd Funding, seen as a modification of crowdsourcing.

Currently, crowdfunding is seen as an independent phenomenon. It means financing various projects by a crowd (a digital crowd), including innovation projects, those from the sphere of business, culture, arts, sports, media, etc. The term crowdfunding is said to have been coined by M. Sullivan who used it on a blog fundavlog in 2006 (Burkett, 2011). When defining crowdfunding one should bear in mind that this phenomenon is shaping now, right in front of our eyes, and in addition to its main goal, i.e. financing projects, it is creating a new trend in business. Król (2013, p. 13) defines crowdfunding as follows: "a type of collection and allocation of capital transferred for the development of a particular project in exchange for a particular return benefit, encouraging a wide range of lenders, also characterized by the use of ICT, a lower barrier to entry and better conditions of transactions than those available on a public market."

Schwienbacher and Larralde (2010, p. 4) define crowdfunding as "an open call, essentially through the Internet, for the provision of financial resources either in the form of a donation or in exchange for some form of a reward and/or voting rights in order to support initiatives for specific purposes." The funds are obtained from Internet users. The idea and the advantage of this mechanism is that it is based on micropayments from a community. An innovation project is financed by a large number of small, one-time payments made by people interested in a project. What prompts them to do so? First and foremost it is a good idea, has creativity, credibility, transparency and a well-told story. It should be added that a project must be completed before a deadline expires, otherwise the auction is closed and all payments are returned.

Crowdfunding as a new mechanism for fundraising stands out due to certain characteristics that allow it to be distinguished from public collections, donations and other traditional forms. The first characteristic feature of crowdfunding is giving cash, almost always in a dematerialized form. There is no possibility of providing support in other forms, e.g. in the form of tangible assets or others. The whole process of capital accumulation takes place by using ICT solutions. The aim of a project being financed by 
crowdfunding, the allocation of resources and the effects of their spending are clearly defined. Crowdfunding does not require any consent from any state body, and can be carried out for personal, business or public reasons. Terms and conditions for raising capital within crowdfunding are better and more favorable than public market conditions. Another characteristic is a wider group of recipients - information about a project is available to a very large group of people, which entails another characteristic, i.e. no restrictions on the access to support a project. The ability to support a project is openly presented, addressed to an unspecified addressee. The last very important and distinguishing characteristic of crowdfunding is a return benefit received for providing financial support (Król, 2013).

\section{Crowdfunding as a source of funding innovation}

Capital is the basis for the development of innovative projects. Polish entrepreneurs indicate that the lack of opportunity for funding innovations, both from internal and external sources, is one of the most significant barriers to innovation - it is confirmed by one in four industrial enterprises and one in five services sector enterprises (Central Statistical Office [CSO], 2015, p. 120). Financial barriers are primarily manifested in the limited access to funds. It notably pertains to micro-enterprises and start-ups. This is due to the low degree of involvement of the banking sector in financing the development of small and medium-sized enterprises. There is also limited access to nonbanking sources of financing, such as venture capital.

Therefore, in view of the difficulties with obtaining the abovementioned external sources of financing, crowdfunding is a new source of fundraising for innovative ventures. As described in the introduction to the article, the current innovation is more frequently co-created by customers or users in the open innovation model, which fits in perfectly with the concept of crowdfunding. A comparison of crowdfunding and other sources of raising capital are presented in Table 1.

From the perspective of investors, the new form of financing allows a direct choice in terms of funds allocation and gives a sense of commitment to the implementation of the project. People involved in community financing can take another look at entrepreneurs and come into direct contact with them, which can further promote the culture of entrepreneurship. Entities funding projects often also form a kind of community to support the funded project or may provide non-financial resources in the form of social knowledge (EC, 2014). 
Table 1. A comparison of crowdfunding and other sources of funding for small venture projects

\begin{tabular}{llllll}
\hline & $\begin{array}{l}\text { Crowdfund- Venture } \\
\text { ing }\end{array}$ & $\begin{array}{l}\text { Business } \\
\text { capital and } \\
\text { private eq- } \\
\text { angels }\end{array}$ & $\begin{array}{l}\text { Stock ex- } \\
\text { changes } \\
\text { and trading } \\
\text { platforms }\end{array}$ & Bank loans & $\begin{array}{l}\text { Leasing } \\
\text { finance/ } \\
\text { trade credit }\end{array}$ \\
\hline $\begin{array}{l}\text { Enabler or- } \\
\text { ganization }\end{array}$ & $\mathrm{x}$ & $\mathrm{x}$ & $\mathrm{x}$ & $\mathrm{x}$ & \\
$\begin{array}{l}\text { Direct inte- } \\
\text { raction }\end{array}$ & $\mathrm{x}$ & $\mathrm{x}$ & $\mathrm{x}$ & $\mathrm{x}$ & $\mathrm{x}$ \\
$\begin{array}{l}\text { Affiliation } \\
\text { of investor/ } \\
\text { investee }\end{array}$ & $\mathrm{x}$ & & $\mathrm{x}$ & & \\
\hline
\end{tabular}

Source: Giudici, Nava, Rossi \& Verecondo (2012).

From the perspective of the company, in addition to funds received, help in obtaining other forms of co-financing is also of crucial importance. In many cases, project initiators are looking for the means to complete only a part of the project. In this situation, obtaining the expected amount on the crowdfunding platform facilitates subsequent financial negotiations with other investors or banks.

Crowdfunding enables companies to not only obtain funding for the project but also to create an engaged community around it and, moreover, it facilitates its promotion. Crowdfunding allows one to verify an idea, check the reaction of potential consumers, and open doors for further refinement of the product, which is especially important for innovation. Crowdfunding can also bring potential benefits for innovation and research and development. It can also contribute to economic growth, community development and job creation with simultaneous financing of innovative projects that do not have the degree of advancement required by traditional financial market sources.

\section{Models of crowdfunding platforms}

Funding obtained from an Internet community can take different forms. Below is presented the classification of crowdfunding according to a type of funding and a form of rewards offered in return for support (Dziuba, 2012, pp. 86-87; UK Interactive Entertainment [UKIE], 2012):

1) Donation model, also known as a charity model, is the most common model where internet users financially support a project, with a specific, philanthropic purpose. In the traditional donation model funders are not rewarded, whilst in a modified model (a sponsorship model), in return for their support, they receive something, e.g. CDs, books, concert tickets, etc.

2) Reward-based model, also called a sponsorship model. 
3) Lending model in which a community offers funds in the form of a direct loan, bypassing banks or other organizations involved in lending; there are two types of this model:

a) microfinance loans' model based on financial aid to the poorest where small amounts are shared;

b) social lending model characterized by large amounts of financial resources; funds are collected and then lent out under certain conditions; loans can be granted for consumption or business purposes;

4) Investment-based model where Internet users on investment platforms invest their own resources in specific projects and ventures in anticipation of specific financial gains; this is a common way of funding start-ups. There are three types of this model:

a) collective investment model involving different groups of people, including business angels, who invest relatively small amounts in the development of a project;

b) investment fund model is based on collective allocation of funds and joint investment; there may be cases where a platform is organized as an investment fund (i.e. venture capital funds); in this model, in exchange for investing in a project funders expect to share profits, e.g. shares, securities. c) investment model, i.e. equity model (securities model), is based on selling shares and transferring ownership rights to online investors; invested funds are usually high.

5) Mixed Model (mixed solutions) is based on a combination of the abovementioned models.

Due to the nature of a project we can distinguish the following: a notfor-profit model aiming to achieve social objectives, and a for-profit model where the aim is a commercial use of a completed project.

\section{Literature on crowdfunding. Chosen empirical findings about crowdfunding}

Crowdfunding is a relatively new phenomenon. The subject literature can be divided into three groups (Moritz \& Block, 2014):

- crowdfunding literature with a focus on capital seekers,

- crowdfunding literature with a focus on capital providers,

- crowdfunding literature with a focus on intermediaries.

Literature focusing on the capital-seeking party is predominantly concerned with the motivations for crowdfunding, the determinants of success, and the legal restrictions of equity-based crowdfunding.

Belleflamme, Lambert and Schwienbacher (2013a, p. 1) compare two forms of crowdfunding: entrepreneurs solicit individuals either to pre-order the product or to advance a fixed amount of money in exchange for a share of future 
profits (or equity). Using a unified model, they show that the entrepreneur prefers pre-ordering if the initial capital requirement is relatively small compared with market size but prefers profit sharing otherwise. In another article Belleflamme, Lambert and Schwienbacher (2013b) identify in their interviews with crowdfunding-experienced entrepreneurs three main reasons for choosing crowdfunding to finance their projects. The collection of funds was stated by all of the respondents as the main reason for using crowdfunding. Other motives mentioned were the attainment of public attention and receiving feedback for their products or services. Gerber, Hui and Kuo (2012) have deepened the analysis by identifying five categories of motivation: fundraising, establishing relationships, receiving legitimacy, replicating successful experiences, increasing awareness about crowdfunders' work through social media. Mollick (2014) examines the geography of crowdfunding using data from Kickstarter to examine the determinants of success in crowdfunding ventures. Mollick uncovers a strong geographic component to the nature of projects, with founders proposing projects that reflect the underlying cultural products of their geographic area. Hemer, Schneider, Dornbusch and Frey (2011) show theoretical and practical analysis of crowdfunding as an alternative to early-stage financing of startups. For this purpose, the authors use interviews and case studies.

Other researchers show that funding success is significantly related to project quality signals such as preparedness, narrative, and others' contribution decisions, as well as individual quality signals like personal characteristics (including gender and race), creditworthiness, and social networks (Kuppuswamy \& Bayus, 2015). Crowdfunding literature focusing on the capital providers is concerned with the motives of capital providers for participating in crowdfunding and the factors that influence the investment decision. Kuppuswamy and Bayus (2013) examine funded projects listed on Kickstarter and show that social information (i.e., other crowdfunders' funding decisions) plays a key role in the success of a project. Brem and Wassong (2014) carried out an analysis of the factors determining the investment decision of individual investors in crowdfunding. The results show that the product plays an important role in investment decisions, especially when it comes to gender differences. Moreover, personal relationships to the startup positively influence the investment decision.

Capital providers in crowdfunding are not just financially motivated. Social reputation and intrinsic motives play a significant role Allison, Davis, Short \& Webb, 2014). So far, there have been only a few research studies on crowdfunding platforms as an intermediary in crowdfunding transactions. For instance, such a study concerning the review of crowdfunding platforms was carried out in Italy by Giudici, Nava, Rossi and Verecondo (2012). The authors used case studies to achieve this aim. Belleflamme and Lambert (2014) in 
their article, discuss the roles and strategies of crowdfunding platforms, which intermediate between entrepreneurs and contributors and they describe the price and non-price strategies that these platforms implement.

\section{RESEARCH PROBLEM AND HYPOTHESES}

Funding innovative projects is one of the most serious problems dealt with by business owners in Poland. The lack of capital for the realization of innovative projects can translate into a deterioration of a company's competitive position. Thus, capital is the basis for the development of innovative enterprises. Polish entrepreneurs indicate that the lack of opportunity for funding innovations, both from internal and external sources, is one of the most significant barriers to innovation - it is confirmed by one in four industrial enterprises and one in five services sector enterprises (CSO, 2015, p. 120). Access to financial resources is also one of the most urgent problems for European SMEs (EC, 2013). For many projects, financing needs are not met by existing sources of financing, which is defined as the funding gap.

Crowdfunding may prove to be a support for entrepreneurship both in terms of improving access to funding and in the context of additional market research and marketing tools that can help entrepreneurs obtain comprehensive knowledge of their customers and promotion in the media (EC, 2014, p. 5). Decisions made in order to choose the sources of financing ventures are strategic ones from the point of view of the company. Making financial decisions is a complex problem. Given the foregoing, the following hypotheses can be formulated:

Hypothesis 1: Polish enterprises finance their innovative projects through crowdfunding platforms in Poland to a small extent.

Hypothesis 2: Polish enterprises are looking to finance their innovative projects on crowdfunding platforms outside Poland.

\section{RESEARCH METHODS}

In order to verify the hypotheses, the author used inductive-deductive inference, desk research analysis and case studies. Desk research method is based on the use of existing secondary data (Makowska, 2013, p. 82). In a thorough and comprehensive desk research many analyses are used, e.g., content analysis (at the stage of seeking sources), the existing statistical data, and also comprehensive analyses and comparisons of historical data, i.e., data collected from websites, balance sheets and financial statements of companies, commercial offers, legal documents, articles, etc. 
The choice of this test method was dictated by a limited possibility to use other research methods and by easy access to data. Such an analysis is also cheaper than doing research or generating reactive data (Hofferth, 2008). Another crucial fact is that in a desk research method an investigator has no effect on the research subject. The same method was employed by Giudici et al. (2012) in their analysis of crowdfunding platforms in Italy.

The study investigated all crowdfunding platforms operating in Poland (both Polish and foreign platforms). This resulted from the aim of the study, which was to identify and evaluate crowdfunding platforms and innovative projects realized on these platforms in Poland. The research covered the years 2014, 2015 and the first half of 2016. The study of the crowdfunding market in Poland and of the opportunities for funding innovations was carried out in two periods: 15 January 2015 (data for 2014) (Kozioł-Nadolna, 2015) and 7 July 2016 (data for 2015 and 2016). The evaluation of the websites of the crowdfunding platforms in Poland was carried out in order to estimate the number of platforms operating in the study period, to define crowdfunding models used by the platforms, the types of projects receiving funding, and the number of innovative projects financed on the platforms.

As a result, the study revealed platforms supporting innovation business projects in the field of engineering and technology. The analysis focused only on donation and investment platforms excluding a lending model.

The case study analysis was another research method used in the article. A case study is a type of research whose aim is to provide an in-depth analysis and explanation of a problem or phenomena of an individual case (Wojcik, 2013; Silverman, 2010). The choice of this method resulted from the nature of the formulated research hypothesis. A case study, in comparison with other research methods, offers the widest range of techniques and tools for data collection and analysis. Another reason justifying the choice of this method is that a single case study is regarded by the author as a pilot study whose aim was to develop preliminary theoretical assumptions paving the way for future research. The example of Sher.ly Inc., was used as a case study of financing an innovative project on the largest crowdfunding platform in the world, namely on Kickstarter.com. The data source was the website of the company, the website of Kickstarter.com and newspaper articles.

\section{RESEARCH RESULTS}

\section{Crowdfunding market in Poland in the years 2014-2016}

The research aim of the article is to identify and evaluate crowdfunding platforms as well as the innovative projects carried out by these platforms 
in Poland in 2014 and 2016. The author used inductive-deductive inference, desk research i.e. the analysis of crowdfunding market in Poland in two research periods and a case study.

The history of the Polish market of crowdfunding, like that of the world's market, is quite short. In 2008, the first social lending platforms such as Kokos. $\mathrm{pl}$ appeared. The oldest operating platform of the donation type is Megatotal. pl established in 2007 (financing music, movies and software). Most platforms were created in the years 2010-2013. Crowdfunding platforms based on the investment model tend to operate for a short period of time.

According to the report, "Moving mainstream - The European Alternative Finance Benchmarking Survey" (2015), the value of the Polish crowdfunding market amounted to 4 million euro. The study covered 11 Polish platforms and identified three factors of dynamic development in the sector; a weakening of the position of traditional financial institutions, technological development, and social and economic changes.

Table 2. An overview of crowdfunding platforms in Poland in 2014-2016 according to their number and the model

\begin{tabular}{llll}
\hline & $\mathbf{2 0 1 4}$ & $\mathbf{2 0 1 5}$ & $\mathbf{2 0 1 6}$ \\
\hline $\begin{array}{l}\text { Number of crowdfunding platforms } \\
\text { Crowdfunding models }\end{array}$ & 18 & 14 & 14 \\
- Investment model & & & \\
- Donation model & 6 & 4 & 4 \\
\hline
\end{tabular}

Based on own research, it can be stated that the number of crowdfunding platforms in Poland decreased. In 2016 there were 14 platforms on the market, whereas in 2014 there were 18 (see Table 2). One can distinguish two models of crowdfunding - a donation and investment model. The number of platforms operating within the two models dropped: in 2014, six platforms operated within the investment model, and 12 within the donation model, whereas in 2015 and 2016 their number dropped to four within the investment model and 10 in the donation model (a sponsorship model). In 2014 and 2015, 10 platforms supported business projects, including innovation projects, whereas in 2016 only 8 platforms did (See Table 3). In 2016 crowdcube platform was inactive. Myseed.pl has still not funded any innovation business projects.

The results of the research on financing innovations through crowdfunding reveal that they are a minority, e.g. in 2014 on PolakPotrafi. pl out of 491 successful projects only 20 concerned technology and design (4\%), whilst in 2015 and 2016 there were over 30. Polakpotrafi.pl is the 
largest Polish platform established in 2011 (Polakpotrafi, 2016). It operates within the donation model (a sponsorship model). This is an "all or nothing" type of funding. Interesting and successful innovation projects completed on the platform PolakPotrafi.pl (2016) are, among others, the following: sheathing for a race car (the students of Rzeszów University of Technology won more than $8000 \mathrm{zt}$ ), New Warsaw - the creation of the body of the car (299 supporters raised $12114.05 \mathrm{zt}$ ), Cohabitat MAKE (808 supporters and $86291.69 \mathrm{z} \nmid)$ ), a project to convert combustion vehicles to electric vehicles (the inventor was supported by 85 people and raised $4639 \mathrm{z}$ )), a project for mobile application used to check food additives (430 supporters, $17251 \mathrm{zł}$ ).

Table 3. An overview of crowdfunding platforms financing business projects in Poland in 2014-2016

\begin{tabular}{llll}
\hline & 2014 & 2015 & 2016 \\
\hline www.beesfund.com & + & + & + \\
www.crowdangels.pl & + & + & + \\
www.crowdcube.pl & + & + & - \\
www.ideowi.pl & + & + & + \\
www.myseed.pl & + & + & + \\
www.odpalprojekt.pl & + & + & + \\
www.polakpotrafi.pl & + & + & + \\
www.wspieram.to & + & + & + \\
www.wspolnyprojekt.pl & + & + & - \\
www.wspolnicy.pl & + & + & + \\
\hline
\end{tabular}

On the second most popular platform in Poland Wspieram.to, in 2014 only three projects were related to technology and three start-ups (Wspieram.to, 2016). The analysis indicates that in 2014 three platforms did not finance any innovation project in the field of engineering and technology (crowdcube. pl) -6 completed projects, none concerned technology; myseed.pl (2015) 11 projects, none concerned technology; wspólnyprojekt.pl (2015) 14 completed projects, none concerned technology). Other platforms carried out several (approx. 16) projects of an innovative character.

Beesfund.com (Beesfund.com, 2016) is a platform supporting only innovation business projects and it operates within the investment model. So far, the platform, apart from its own project, has successfully completed two projects: an asset and a payment system Bitcoin ( 5000 shares amounting to $200000 \mathrm{zt}$ ), and a brewery project (10000 shares amount to $400000 \mathrm{z} \nmid$ ). So far, 5 projects have applied for funding. In the near future, the platform is planning two editions. The results obtained from the study positively verify 
the first research hypothesis that Polish enterprises finance their innovative projects through crowdfunding platforms in Poland to a small extent.

The research carried out in Poland indicates that platforms operating within the donation model record the highest activity. Siepomaga.pl, supporting initiatives primarily related to medical treatment, raised almost 84 million zt in more than 3600 auctions. Among the platforms operating within the sponsorship model one can distinguish those specializing in raising funds for specific types of projects, or the so-called supermarkets (wide variety of projects). The second part of the analysis, based on the abovementioned conclusions, allows us to present the example of a Polish company Sher.ly, which successfully raised funds on the American platform called Kickstarter. com.

\section{Funding innovation on Kickstarter.com - a case study of Sher.ly About the company and its innovation}

Sher.ly Inc. (sher.ly, 2016) was founded in 2009 in Krakow, Poland by two visionaries: Marek Cieśla and Błażej Marciniak - both experienced development entrepreneurs in IT solutions. Sher.ly is based in Palo Alto, Calif. and in Krakow, Poland. Sher.ly is a private cloud solution designed for security conscious businesses looking to take back control of their sensitive data. Sher. ly stop valuable information from leaving an organization and help control access to data with a security focused solution that offers robust reporting, simple access management controls, and easy to use auditing tools. Unlike other file sharing solutions, Sher.ly does not distribute copies of the data but grants access to it instead.

\section{Funding Sherlybox on Kickstarter.com and its objectives}

In 2014, a start-up Sher.ly (2016) prepared a new version of Sherlybox. Its production was financed by a fund-raiser announced in 2014 on Kickstarter. com (2016). Since the launch of Kickstarter, on 28 April 2009, 11 million people have backed its projects, \$2.5 billion has been obtained, and 108687 projects have been successfully funded. The company collected USD 154106, which was $223 \%$ of the assumed amount. The Polish team succeeded as, after six days, it had collected all the resources needed for the project 69 thousand dollars. The project was supported by 896 people. The most frequently chosen form of support was to transfer USD 199 to the creators' account in exchange for a reward, i.e. one's own Sherlybox equipped with a 1 TB hard disc drive (HDD).

According to the authors, the project's main goal was not raising money for innovation. The aim was to present Sher.ly's software to a wider 
and more conscious group of users. Additionally, it was launched to gain publicity intended to generate investment. Kickstarter, above all, is a great platform for PR and an objective test checker to see if a product satisfies the needs of a target group of customers. The choice of a crowdfunding platform largely depends on the type of product. If your product or service solves a local problem or satisfies a local need, a local crowdfunding platform would be a better choice. For Sher.ly, the choice of Kickstarter.com was very important and not accidental. Although Indiegogo had been on the market longer, Kickstarter was perceived as more popular due to, among others, the remarkable success of projects such as Pebble - a smartwatch. Indiegogo was not so popular and it had fewer supporters than Kickstarter.com. Based on the case study of Sher.ly Inc., the second research hypothesis, which assumes that Polish companies are looking to finance their innovative projects on crowdfunding platforms outside Poland, was positively verified.

\section{DISCUSSION}

In May 2016, the European Commission published a report Crowdfunding in the EU Capital Markets Union (European Commission [EC], 2016). The report identified 510 live platforms as active in the EU as at 31 December 2014. Of these, 502 platforms were located in 22 Member States, while 8 platforms were located in other countries (Australia, Canada, China, New Zealand and the United States). Most platforms were located in the United Kingdom (143), followed by France (77) and Germany (65). The majority of platforms were involved in reward-based crowdfunding (30\%), followed by platforms involved in equity crowdfunding (23\%) and loan-based crowdfunding (21\%).

Crowdfunding has been developing rapidly in some Member States. It is estimated that $€ 4.2$ billion were successfully raised through crowdfunding platforms in 2015 across the EU, of which $€ 4.1$ billion were raised through crowdfunding models entailing a financial return. Project data from the platforms covered by the study showed a total of $€ 2.3$ billion successfully raised in 2013-2014. The largest single projects raised $€ 6.1$ million (equity) and $€ 5.0$ million (loan). Across the EU, between 2013 and 2014, amounts raised through equity crowdfunding platforms grew by $167 \%$, and amounts raised through loan crowdfunding platforms grew by $112 \%$. According to the report, one of the most promising forms of financing innovative entrepreneurs and start-ups is equity crowdfunding. In the European Union, in 2015, there were 60 platforms of this type that, altogether, conducted 836 campaigns and raised more than $€ 420$ million.

In Poland, the equity crowdfunding market is still relatively small. According to Crowdsurfer.com (Crowdsurfer.com, 2016), in 2015 the value 
of investments amounted to only $€ 216000$, with an average investment value of approximately $€ 17000$. Having performed an analysis of the Polish crowdfunding market in the period between 2014-2016 similar conclusions can be drawn. There are four actively operating platforms within the equity model. However, they are characterized by a small number of completed projects (a dozen or so). This model of crowdfunding seems to be the best to financially support companies with innovative solutions. The Polish market compared to the world market seems to be in the early stages of development.

However, each year the number of projects, payments and the amounts paid in on donation platforms in Poland are increasing. The two platforms, Polakpotrafi.pl and Wspieramto.pl, are developing rapidly (2016). The results obtained from the study positively verify the first research hypothesis that Polish enterprises finance their innovative projects through crowdfunding platforms in Poland to a small extent. There are various reasons underlying this situation. One of these may be entrepreneurs' unfamiliarity with this tool and the lack of knowledge of its benefits. The second reason may be the reluctance to prepare a professional business offer. It is not enough to register on a website and submit an application. Preparation of an offer requires great commitment on the part of its authors and a lot of promotional activities. Moreover, another reason may be an unfavorable legal environment, especially in the case of the investment model, i.e. equity or securities model. The vagueness of the law and the lack of tax benefits may also lead to the discouragement of investors.

The article presents the example of a Polish start-up enterprise, which was successful in searching for funds not on Polish platforms, but on the world's largest platform Kickstarter.com. The second research hypothesis, which assumes that Polish companies are looking to finance their innovative projects on crowdfunding platforms outside Poland, was positively verified. The creators of the innovation called Sherlybox wanted to introduce their product onto the world market, and that was one of the reasons why they chose Kickstarter - a leader of crowdfunding in the world. The choice of this solution is confirmed by the creators of the platforms Polakpotrafi.pl and Wspieramto.pl. They believe it is difficult to obtain business funding on Polish crowdfunding platforms. It is better to look for it on such global platforms as Kickstarter and Indiegogo. When it comes to a business project or a start-up, they say it is well worth raising funds within the equity crowdfunding. The biggest problem, however, is a lack of interest on the part of the Poles.

\section{CONCLUSION}

The crowdfunding market in Poland is growing. Most social funding platforms in Poland were established after 2010. Based on the analysis, it can be stated 
that the Polish market of crowdfunding can be divided into two streams consistent with crowdfunding models. First is the donation crowdfunding, which is a rapidly growing form of obtaining capital for planned projects, primarily in the field of music, games or sports. This is a popular way to fulfill different passions and to make one's dreams come true. The other stream is investment crowdfunding, which can be seen as an alternative source of finance; however Polish platforms are still not popular.

Based on the research, it can be stated that both hypotheses formulated in this article were positively verified, which means that Polish enterprises finance their innovative projects through crowdfunding platforms in Poland to a small extent and that Polish enterprises are looking to finance their innovative projects on crowdfunding platforms outside Poland. It should be noted, however, that Polish companies, in spite of having problems with raising capital for projects, show little interest in the alternative sources of financing, such as crowdfunding. It can be noticed that Polish innovation projects are looking for financing on global platforms (such as Kickstarter). It is too early to discuss the great importance of crowdfunding for the Polish financial market. From a theoretical and scientific perspective it would be interesting to research further the possibilities of crowdfunding.

Decisions made, in order to choose the sources of financing ventures, are strategic ones from the point of view of the company. Making financial decisions is a complex problem. There still remains an open question of what factors influence the decision about funding projects through crowdfunding, and what factors imply the adoption of a different model of a capital structure. Further studies on the reasons why Polish companies seek capital on international crowdfunding platforms will be of interest. Thus, it seems that in the face of the dynamic development of crowdfunding in the world, this process in Poland will continue to be an important and interesting research problem paving the way for future studies and further evaluation.

\section{References}

Ahmed, P. K. (2000). Sixth generation innovation: innovation management systems into the future. European Journal of Innovation Management, 3, 112-114.

Allison, T. H., Davis, B. C., Short, J. C., \& Webb, J. W. (2014). Crowdfunding in a prosocial microlending environment: Examining the role of intrinsic versus extrinsic cues. Entrepreneurship Theory and Practice, 39(1), 5373.

Baruk, J. (2006). Zarzqqdzanie Wiedzq i Innowacjami. Toruń, Poland: Wydawnictwo Adam Marszałek. 
Belleflamme, P., Lambert, T., \& Schwienbacher, A. (2013a). Crowdfunding: Tapping the right crowd. Journal of Business Venturing, 29(5), 585-609.

Belleflamme, P., Lambert, T., \& Schwienbacher, A. (2013b). Individual crowdfunding practices. Venture Capital, 15(4), 313-333.

Belleflamme, P., \& Lambert, T. (2014). Crowdfunding: Some empirical findings and microeconomic underpinnings. SSRN paper. Retrieved from http:// ssrn.com/abstract $=2437786$

Brem, A., \& Wassong, N. (2014). Wer investiert warum? Eine Analyse von Investmententscheidungen bei Crowdfunding-Projekten. ZfKE Zeitschrift für KMU und Entrepreneurship, 62, 31-55.

Burtan, G. (2016, July 5). Najwięcej wpłacaja gracze. Tłumaczymy, jakie projekty i platformy crowdfundingowe zapewniaja sukces finansowy. Retrieved from: http://innpoland.pl/127929,najwiecej-wplacaja-graczetlumaczymy-jakie-projekty-i-platformy-crowdfundingowe-zapewniajasukces-finansowy

Chesbrough, H. W. (2003). Open Innovation: The New Imperative for Creating and Profiting from Technology. Boston: Harvard Business School Press.

Dziuba, D. T. (2012). Rozwój systemów crowdfundingu-modele, oczekiwania i uwarunkowania. Problemy Zarządzania 10(3), 83-103.

Equity Crowdfunding jednq z najbardziej obiecujqcych form finansowania europejskich startupów (2016, July 5). Retrieved from: http://biznestuba. pl/fundusze-unijne/equity-crowdfunding-jedna-z-najbardziejobiecujacych-form-finansowania-europejskich-statupow/

European Commission. (2013).2013 SMEs' Access to Finance survey. Retrieved from http://ec.europa.eu/DocsRoom/documents/7864/attachments/1/ translations/en/../native

European Commission. (2016). Crowdfunding in the EU Capital Markets Union. SWD 154 final, Brussels.

Gerber, E., Hui, J., \& Kuo, P. (2012). Crowdfunding: Why people are motivated to post and fund projects on crowdfunding platforms. In CSCW Workshop. Retrieved from http://www.juliehui.org/wp-content/uploads/2013/04/ CSCW_Crowdfunding_Final.pdf

Giudici, G., Nava, R., Rossi L., \& Verecondo, Ch. (2012). Crowdfunding: The new frontier for financing entrepreneurship? SSRN paper. Retrieved from http://ssrn.com/abstract=2157429

Główny Urząd Statystyczny. (2015). Działalność Innowacyjna Przedsiębiorstw w Polsce. Poland: Warsaw.

Hemer, J., Schneider, U., Dornbusch, F., \& Frey, S. (2011). Crowdfunding und andere Formen informeller Mikrofinanzierung in der Projekt-und Innovationsfinanzierung. Stuttgart, Germany: Fraunhofer Verlag.

Hofferth, L. (2005). Secondary data analysis in family research. Journal of Marriage and Family, 67(4), 891-907.

Howe, J. (2006). The rise of crowdsourcing. Wired Magazine, June.

Janasz, W., \& Kozioł, K. (2007). Determinanty Działalności Innowacyjnej Przedsiębiorstw. Warszawa, Poland: PWE. 
Janasz, W., Kozioł-Nadolna, K. (2011). Innowacje w Organizacji. Warszawa, Poland: PWE.

Komisja Europejska. (2014). Uwolnienie potencjału finansowania społecznościowego w Unii Europejskiej. Retrieved from https://mac.gov. pl/../komunikat_komisji_europejskiej_o_finansowaniu_spolecznosci.

Kozioł-Nadolna, K. (2015). Crowdfunding jako źródło finansowania innowacyjnych projektów. Zeszyty Naukowe Uniwersytetu Szczecińskiego, 854, 671-683.

Król, K. (2013). Finansowanie społecznościowe jako źródło finansowania przedsięwzięć w Polsce. Retrieved from Crowdfunding.pl

Kuppuswamy, V., \& Bayus, B. L. (2013). Crowdfunding creative ideas: The dynamics of project backers in Kickstarter. UNC Kenan-Flagler Research Paper. Retrieved from http://ssrn.com/abstract $=2234765$

Kuppuswamy, V., \& Bayus, B. L. (2015). A Review of Crowdfunding Research and Findings. Handbook of New Product Development Research (Forthcoming). Retrieved from http://ssrn.com/abstract=2685739

Makowska, M. (2012). Analiza Danych Zastanych. Przewodnik dla Studentów. Warszawa: Scholar.

Malinowski, B. (2016). Co warto wiedzieć o crowdfundingu udziałowym nowej formie finansowania startupów? Retrieved from http://www. pi.gov.pl/PARP/chapter_86197.asp?soid=39A46D3EAB2B4C17B40E67FC E959072C

Mollick, E. R. (2014). The dynamics of crowdfunding: An exploratory study. Journal of Business Venturing 29(1), 1-16.

Moritz, A., \& Block, J. H. (2014). Crowdfunding: A literature review and research directions. Retrieved from http://ssrn.com/abstract $=2554444$

Nobelius, D. (2004). Towards the sixth generation of R\&D management. International Journal of Project Management, 22(5), 369-375.

Organization for Economic Co-operation and Development. (2009). Interim Report On The OECD Innovation Strategy. OECD.

Organization for Economic Co-operation and Development. (2012). Science, Technology and Industry Outlook. OECD.

Pierrakis, Y., \& Collins, L. (2013). Crowdfunding: A New Innovative Model of Providing Funding to Projects and Businesses. Retrieved from http:// ssrn.com/abstract $=2395226$

Rothwell, R. (1992). Successful industrial innovation: Critical factors for the 1990's. R\&D Management, 22, 221-240.

Schumpeter, J. (1960). Teoria Rozwoju Gospodarczego. Warszawa, Poland: PWE.

Schwienbacher, A., \& Larralde, B. (2010).Crowdfunding ofsmallentrepreneurial ventures. Handbook of Entrepreneurial Finance. Oxford University Press (Forthcoming). Retrieved from http://ssrn.com/abstract=1699183

Silverman, D. (2010). Prowadzenie Badań Jakościowych. Warszawa: Wydawnictwo Naukowe PWN. 
Teece, D. (1988). Technological change and the nature of the firm. In G. Dosi, C. Freeman, R. Nelson, G. Silverberg \& L. Soete (Eds.), Technical change and economic theory. New York-London: Pinter Publishers.

UK Interactive Entertainment. (2012, February). Crowd Funding Report: A Proposal to Facilitate Crowd Funding in the UK.

Wójcik, P. (2013). Znaczenie studium przypadku jako metody badawczej w naukach o zarządzaniu. E-mentor, 1(48), 17-22.

Zhang, Z., Wardrop, R., Rau, P. R., \& Gray, M. (2015). Moving Mainstream. The European Alternative Finance Benchmarking Survey. University of Cambridge and EY.

\title{
Internet sources
}

https://crowdsurfer.com/info

https://polakpotrafi.pl

https://sher.ly/

https://wspieram.to/

https://wspolnyprojekt.pl

https://www.crowdcube.pl/

https://www.kickstarter.com

https://www.kickstarter.com/projects/sherly/sherlybox-a-private-andshareable-cloud-on-your-de

https://www.siepomaga.pl/

\begin{abstract}
Polish)
Finansowanie projektów innowacyjnych jest jednym z najpoważniejszych problemów, z jakimi maja do czynienia właściciele przedsiębiorstw w Polsce. Dlatego w zwiqzku z trudnościami z pozyskiwaniem zewnętrznych źródeł finansowania, crowdfunding stanowić może nowe źródło pozyskiwania środków na przedsięwzięcia innowacyjne. Przedmiotem rozważań w artykule jest zatem crowdfunding jako sposób na pozyskanie kapitału na realizację projektów. Celem badawczym artykułu jest identyfikacja i ocena platform crowdfundingowych i realizowanych na nich projektów innowacyjnych w Polsce w latach 2014-2016. W pierwszej części przedstawiono istotę crowdfundingu, cechy charakterystyczne, modele jego działania. Scharakteryzowano crowdfunding jako źródło finansowania innowacji. W części empirycznej posłużono się wnioskowaniem indukcyjno-dedukcyjnym, analiza desk research (analiza rynku crowdfundingu $w$ Polsce $w$ dwóch okresach badawczych) i analizq studium przypadku. Przedstawiono wyniki badań dotyczqcych polskiego rynku crowdfundingu w latach 2014-2016 (oszacowano ilość funkcjonujqcych platform w danym okresie badawczym, model crowdundingu stosowanego przez platformę, rodzaj projektów uzyskujqcych finansowanie i liczbę projektów innowacyjnych finansowanych na platformach. Przedstawiono także analize przypadku finansowania innowacji na platformie Kickstarter.com przez polska firmę Sher.ly.
\end{abstract}

Keywords: innowacje, crowdfunding, finansowanie innowacji, Polska. 


\section{Biographical note}

Katarzyna Kozioł-Nadolna is professor of economy at the Faculty of Economics and Management, University of Szczecin, Poland. Her research interests focus on factors determining the innovativeness of enterprises in Poland and the European Union, internationalization of research and development activity conducted by enterprises in Poland, innovative process models and the impact of innovative policy pursued by state on innovative processes. She is an author of more than 140 academic publications. She conducts classes in enterprise management, innovation management, logistics management, project management, strategic management, production management, quality management, fixed asset management. 
